\title{
CXCL9 and CXCL10 predict survival and are regulated by cyclooxygenase inhibition in advanced serous ovarian cancer
}

\author{
Holger Bronger ${ }^{\star}, 1$, Judith Singer ${ }^{1}$, Claudia Windmüller ${ }^{1}$, Ute Reuning ${ }^{1}$, Daniela Zech ${ }^{1}$, Claire Delbridge ${ }^{2}$, \\ Julia Dorn ${ }^{1}$, Marion Kiechle ${ }^{1}$, Barbara Schmalfeldt ${ }^{1,3}$, Manfred Schmitt ${ }^{1}$ and Stefanie Avril ${ }^{2,4}$ \\ ${ }^{1}$ Department of Gynecology and Obstetrics, Klinikum rechts der Isar, Technical University of Munich, Ismaninger Straße 22, 81675 \\ Munich, Germany and ${ }^{2}$ Department of Pathology, Technical University of Munich, Ismaninger Straße 22, 81675 Munich, Germany
}

\begin{abstract}
Background: Tumour-infiltrating lymphocytes (TILs) are associated with improved survival in several epithelial cancers. The two chemokines CXCL9 and CXCL10 facilitate chemotactic recruitment of TILs, and their intratumoral accumulation is a conceivable way to improve TIL-dependent immune intervention in cancer. However, the prognostic impact of CXCL9 and CXCL10 in highgrade serous ovarian cancer (HGSC) is largely unknown.
\end{abstract}

Methods: One hundred and eighty four cases of HGSC were immunohistochemically analyzed for CXCL9, CXCL10. TILs were assessed using CD3, CD56 and FOXP3 staining. Chemokine regulation was investigated using the ovarian cancer cell lines OV-MZ-6 and SKOV-3.

Results: High expression of CXCL9 and CXCL10 was associated with an approximately doubled overall survival ( $n=70, C X C L 9$ : HR 0.41; $P=0.006$; $C X C L 10: H R$ 0.46; $P=0.010$ ) which was confirmed in an independent validation set $(n=114 ; C X C L 9: H R$ 0.60; $P=0.019$; CXCL10: HR 0.52; $P=0.005$ ). Expression of CXCR3 ligands significantly correlated with TILs. In human ovarian cancer cell lines the cyclooxygenase (COX) metabolite Prostaglandin E2 was identified as negative regulator of chemokine secretion, whereas COX inhibition by indomethacin significantly upregulated CXCL9 and CXCL10. In contrast, celecoxib, the only COX inhibitor prospectively evaluated for therapy of ovarian cancer, suppressed NF- $\kappa \mathrm{B}$ activation and inhibited chemokine release.

Conclusion: Our results support the notion that CXCL9 and CXCL10 exert tumour-suppressive function by TIL recruitment in human ovarian cancer. COX inhibition by indomethacin, not by celecoxib, may be a promising approach to concomitantly improve immunotherapies.

Ovarian cancer is one of the leading causes for cancer-related death among women in the Western world (Kandalaft et al, 2011). Systemic treatment strategies are still more or less limited to chemotherapy, and radical surgical debulking is a necessary prerequisite for enduring progression-free survival (PFS). In recent years, evidence has emerged that ovarian cancers are immunogenic tumours, starting with the observation that subsets of tumourinfiltrating lymphocytes (TILs) are strongly associated with prolonged PFS and overall patient survival (Zhang et al, 2003;
Sato et al, 2005). Moreover, the TIL composition of the tumour microenvironment is associated with chemosensitivity and optimal cytoreductive surgery (Gasparri et al, 2015). This has prompted the development of novel strategies for immunologic therapy, such as treatment regimens containing interleukin-2 (IL-2), monoclonal antibody therapies (e.g., directed to VEGF, CA-125, HER3 and folate receptor- $\alpha$ ), immune checkpoint inhibition (e.g., against PDL1, PD-1 and CTLA-4) or cancer vaccinations (Kandalaft et al, 2011; Bellati et al, 2012, 2013; Leone Roberti Maggiore et al, 2013).

\footnotetext{
*Correspondence: Dr H Bronger; E-mail: holger.bronger@|rz.tum.de

${ }^{3}$ Current address: Department of Gynecology, University Medical Center Hamburg-Eppendorf, Martinistrasse 52, 20246 Hamburg, Germany

${ }^{4}$ Current address: Department of Pathology, Case Western Reserve University School of Medicine, University Hospitals Case Medical Center, Cleveland, Ohio, USA
} 
However, indispensable for the success of these immunotherapies is a sufficient trafficking of the immune effector cells into the tumour (Abastado, 2012).

The two chemokines and CXCR3 receptor ligands CXCL9 and CXCL10 mediate the recruitment of tumour-suppressive CXCR3 ${ }^{+}$ $\mathrm{T}$ cells and natural killer (NK) cells into solid cancers (Yang et al, 2006; Gorbachev et al, 2007; Wendel et al, 2008). Correspondingly, a high intratumoral concentration of these chemokines is associated with a higher lymphocytic infiltrate and an improved survival in several malignancies (Zhang et al, 2003; Kondo et al, 2004; Suyama et al, 2005; Specht et al, 2009; Denkert et al, 2010). Raising intratumoral chemokine concentrations could thus improve immunosurveillance by an intensified infiltration of TILs, which could in turn augment the efficacy of immunotherapeutic approaches that depend on the presence of these cells (Kohrt et al, 2012; Shuptrine et al, 2012). Recently, two genomic classifications of ovarian cancer described CXCR3-binding chemokines as characteristic features of so-called 'immunoreactive subtypes' associated with a higher lymphocytic infiltrate and a more favourable prognosis (Tothill et al, 2008; The Cancer Genome Atlas Research Network, 2011). However, CXCL9 and CXCL10 can also mediate chemotaxis of tumour-promoting cells such as regulatory $\mathrm{T}$ cells (Redjimi et al, 2012), and their expression is associated with a worse prognosis in some entities (Hsin et al, 2013; Lunardi et al, 2014; Tymoszuk et al, 2014). Although most studies indicate a tumour-suppressive function of CXCR3 chemokines, regulation and prognostic impact that provide an indication of their actual net effect have not been investigated in ovarian cancer so far.

The COX system is a potential pharmacologic target to augment intratumoral CXCR3 ligand concentrations (Bronger et al, 2012). Preclinical data show that an overexpression of both COX isoenzymes COX-1 and COX-2 is significantly associated with a lower number of $\mathrm{CD}^{+}$TILs and a worse prognosis in human ovarian cancer (Denkert et al, 2002; Liu et al, 2009). We therefore hypothesise that COX inhibition may lead to enhanced lymphocytic tumour infiltration by inducing the expression of CXCR3-binding chemokines. Considering the number of available COX inhibitors with well-defined pharmacologic profiles this approach seems conceivable as an adjunct for ovarian cancer immunotherapy.

In the present study, we explored the prognostic impact of CXCL9 and CXCL10 in high-grade serous ovarian cancer (HGSC). We demonstrate that the expression of both chemokines is a strong and independent predictor of improved patient survival. In synopsis with our in vitro results presented below, we propose COX inhibition with indomethacin as a pharmacologically feasible way to improve immune therapies in ovarian cancer by increasing TILs through augmenting CXCL9 and CXCL10 release from ovarian cancer cells.

\section{MATERIALS AND METHODS}

Human tissue samples and patient characteristics. For the immunohistochemical studies, we used formalin-fixed, paraffinembedded specimens from 184 patients with HGSC stage FIGO III or IV (International Federation of Gynecology and Obstetrics). Patient characteristics for the discovery cohort $(n=70)$ and the validation cohort $(n=114)$ are given in Supplementary Table 1. Patients were treated at the Department of Gynecology and Obstetrics, Technical University of Munich (Munich, Germany), between 1992 and 2010. All patients underwent standard debulking surgery, followed by adjuvant platinum-based chemotherapy. Complete pelvic and paraaortal lymphonodectomy was usually performed in most FIGO III patients, also in some FIGO IV patients according to the consensus recommendations at that time. In $\sim 15 \%$ of patients, no lymphonodectomy was performed. Written informed consent was obtained from all patients. Two distinct but overlapping patient cohorts were utilised for assessment of chemokine expression by immunohistochemistry (discovery set, $n=70$ ) and by enzyme-linked immunosorbent assay (ELISA; $n=39$ ), including 22 patients belonging to both cohorts. For the quantitative assessment of chemokine content by ELISA, 39 tumour extracts derived from fresh-frozen ovarian cancer samples were utilised. Seventeen out of 39 (43.6\%) patients had no residual tumour after surgery, 11 out of $39(28.2 \%)$ had residual tumour below $1 \mathrm{~cm}$ and 11 out of $39(28.2 \%)$ above $1 \mathrm{~cm}$. Twelve patients had node-negative disease (30.8\%), 19 had nodepositive disease $(48.7 \%)$ and 8 patients had an unknown nodal status $(20.5 \%)$.

Reagents and cell lines. OV-MZ-6 (Möbus et al, 1992) and SKOV-3 (American Type Culture Collection, Manassas, VA, USA) human ovarian cancer cell lines were cultured in a humidified 5\% (v/v) $\mathrm{CO}_{2}$ atmosphere at $37^{\circ} \mathrm{C}$ in DMEM supplemented with glutamine, $10 \%(\mathrm{v} / \mathrm{v})$ fetal calf serum, $10 \mathrm{mM}$ HEPES and $20 \mu \mathrm{g} \mathrm{ml}^{-1}$ gentamycin.

Antibodies. Monoclonal mouse antibodies were raised against CXCL9 (clone 49106, R\&D Systems, Minneapolis, MN, USA), CXCL10 (clone sc-101500, Santa Cruz Biotechnology, Santa Cruz, CA, USA), CD3 (MRQ-39), CD56 (MRQ-42, Cell Marque, Rocklin, CA, USA), FOXP3 (236A/E7, eBioscience, San Diego, CA, USA), COX-1 (clone COX111, Invitrogen, Camarillo, CA, USA), COX-2 (clone CX229, Cayman Chemicals, Ann Arbor, MI, USA), glyceraldehyde 3-phosphate dehydrogenase (GAPDH, clone $6 \mathrm{C} 5$, Millipore, Billerica, MA, USA) and horseradish peroxidaseconjugated goat anti-mouse IgG (Jackson ImmunoResearch, Burlington, ON, USA).

Immunohistochemistry. Immunohistochemical staining for CXCL9 and CXCL10 was performed similar to our previously described protocol (Bronger et al, 2012). Consecutive sections were used for different antibodies to allow for comparability between stainings. Normal serous epithelium from unaffected fallopian tubes was used as control tissue on each slide. For CXCL10 staining, an avidin-biotin block was applied before blocking with goat serum. Final antibody concentrations were as follows: anti-CXCL10 $1 \mu \mathrm{g} \mathrm{ml}^{-1}$, anti-COX-1, anti-COX-2 $10 \mu \mathrm{g} \mathrm{ml}^{-1}$ and anti-FOXP3 $2.5 \mu \mathrm{g} \mathrm{ml}^{-1}$ in antibody diluent (Dako, Glostrup Denmark, S2022). Staining for CD3 and CD56 was performed on a BenchMark XT automated IHC staining instrument (Ventana, Tucson, AZ, USA), using XT ultraView DAB v3 (Zytomed Systems, Berlin, Germany) staining procedure according to the manufacturer's instructions. Following deparaffinization, antigen retrieval was performed by incubation for $30 \mathrm{~min}$ at $95^{\circ} \mathrm{C}$, pH 8.4. Primary antibodies (CD3 1:500, CD56 1:4) were incubated for $30 \mathrm{~min}$ at RT, followed by the detection of primary antibody using the UV HRP UNIV MULT and UV DAB kits (Ventana) and counterstaining with haematoxylin.

For CXCL9, CXCL10, COX-1 and COX-2, cytoplasmic staining of tumour cells was assessed semi-quantitatively as absent (0), weak $(1+)$, moderate $(+)$ or strong $(3+)$ staining intensity. As no considerable intratumoral heterogeneity in staining was observed for all antibodies used, the immunohistochemical assessment of protein expression was based on staining intensity alone. For each antibody, a control block of HGSC tissue previously classified as $2+$ was mounted on every glass slide to account for in-run and inter-run differences in staining intensity.

For evaluation of $\mathrm{CD}^{+}$TILs or $\mathrm{CD}^{+} 6^{+} \mathrm{NK}$ cells, only inflammatory cells within tumour cell islets or in intra- or peritumoral stroma (defined as $100 \mu \mathrm{m}$ peritumoral margin) were counted. Inflammatory infiltrate was classified as weak $(1+)$ when loosely scattered inflammatory cells were present, moderate $(2+)$ when at least 2 intra- or peritumoral foci of $>20$ clustered 
inflammatory cells were detected and strong $(3+)$ when 5 or more intra- or peritumoral foci of $>20$ clustered inflammatory cells were detected. FOXP3 ${ }^{+}$lymphocytes were counted in 10 highpower fields (HPFs) and scored as 0 (no cells), $1+(1-10$ cells/10 HPFs), $2+$ (11-40 cells/10 HPFs) and $3+$ ( $>40$ cells/10 HPFs).

Assessment of CXCL9 and CXCL10 concentrations in human tissue extracts. Fresh ovarian cancer tissue homogenates were prepared as described (Schmalfeldt et al, 1995). Tissue Extracts were diluted $1: 4$ in 1\% BSA/PBS and subjected in duplicates to the analysis, using the DuoSet ELISA kit (R\&D Systems).

Western blot analysis. Immunoblotting onto the nitrocellulose membranes and immunostaining were performed as described (Bronger et al, 2005, 2012). Primary antibodies were applied as follows: anti-COX-1 $2 \mu \mathrm{g} \mathrm{ml}^{-1}$, anti-COX-2 $2 \mu \mathrm{g} \mathrm{ml}^{-1}$, antiGAPDH $0.1 \mu \mathrm{g} \mathrm{ml}^{-1}$.

Modulation of chemokine secretion from human ovarian cancer cells. OV-MZ-6 and SKOV-3 cells were plated on 12-well cell culture plates and grown to $\sim 70-80 \%$ confluency, washed in PBS and starved for $24 \mathrm{~h}$ in FCS-free medium. The medium was then replaced and the respective test reagents added as indicated. After $24 \mathrm{~h}$, cell culture supernatants were collected and stored at $-20^{\circ} \mathrm{C}$ until further use. Each experiment was performed in triplicates and repeated at least three times. Subsequently, the culture supernatants were subjected to ELISA for assessment of CXCL9 and CXCL10 concentrations, using the DuoSet ELISA kits DY392 and DY266 (R\&D Systems). MTT assays were performed as described (Bronger et al, 2012).

Transient cell transfection and luciferase reporter gene assay for Rel transcription factors (assesment of NF- $\kappa$ B activation). For monitoring Rel transcription factor activations upon stimulation by tumour necrosis factor (TNF)- $\alpha$ and celecoxib, reporter gene assays were conducted as previously described (Müller et al, 2013).

Statistical analysis. Univariate survival analyses were plotted using the Kaplan-Meier method and analysed with the log-rank test. For multivariate survival analyses a Cox proportional hazard model was used. Spearman's rank coefficient was used to describe the correlations between CD3, CD56, FOXP3, COX-1, COX-2 and the CXCR3 ligands, respectively. Results of the cell culture stimulation experiments were evaluated using mean values taken from at least three independent experiments and analysed using the Mann-Whitney test (SPSS Statistics Software, Version 21.0, SPSS Inc., Chicago, IL, USA). Results are given as mean \pm s.e.m., if not indicated otherwise. Statistical significance was defined as ${ }^{\star} P \leqslant 0.05,{ }^{* *} P \leqslant 0.005$ or ${ }^{* * *} P \leqslant 0.001$.

\section{RESULTS}

Expression and cellular localisation of CXCL9 and CXCL10 in serous ovarian cancer tissues. CXCL9 and CXCL10 expression was analysed semi-quantitatively by immunohistochemical staining of 70 (discovery set) and 114 (validation set) surgical specimens of patients with HGSC. In line with prior reports (Furuya et al, 2007; Rainczuk et al, 2014), both proteins were localised predominantly in the cytoplasm of the tumour cells (Figure 1A and B). In addition, weak background staining was observed in some endothelial cells, leukocytes and in the extracellular matrix. In the discovery set, tumour cell CXCL9 expression was scored 0 ( 2 out of $70,3 \%), 1+(13$ out of $70,19 \%), 2+(38$ out of $70,54 \%)$ and $3+(17$ out of $70,24 \%)$. Tumour cell CXCL10 expression was scored 0 ( 4 out of $64,6 \%), 1+(18$ out of $64,28 \%), 2+(29$ out of $64,45 \%)$ and $3+(13$ out of $64,21 \%)$. In six cases, CXCL10 expression was not assessable due to technical difficulties. In the validation set, tumour cell CXCL9 expression was scored 0 (4 out of $104,4 \%), 1+(39$ out of $104,37 \%), 2+(48$ out of $104,46 \%)$ and $3+(13$ out of 104,13\%). Tumour cell CXCL10 expression was scored $1+(34$ out of $111,31 \%), 2+(63$ out of $111,57 \%)$ and $3+(14$ out of $111,12 \%)$. Thus, the majority of serous ovarian cancer samples showed a strong expression (scores $2+$ and $3+$ ) of both chemokines (66.7\% for CXCL9 and 68\% for CXCL10). There was no correlation between the immunohistochemical expression of CXCL9 and CXCL10 with each other.

For absolute quantification of CXCL9 and CXCL10 protein, we measured both chemokines by ELISA. Concentrations were determined in tumour extracts derived from 39 HGSCs (Figure 1C). CXCL9 $\left(2.49 \pm 0.4 \mu \mathrm{g} \mathrm{mg}^{-1}\right.$ total protein) was approximately sevenfold more abundant than CXCL10 $\left(0.35 \pm 0.07 \mu \mathrm{g} \mathrm{mg}^{-1}\right.$ total protein; $\left.P<0.0001\right)$. There was a moderate correlation between the expression levels of CXCL9 and CXCL10 ( $r=0.518 ; P=0.001$; Figure 1D).

CXCL9 and CXCL10 expression is associated with improved patient survival in advanced HGSC. Among clinicopathological parameters, residual tumour mass after surgery was the only parameter significantly associated with reduced patient survival in both the discovery and the validation cohort (Supplementary Table 2).

To back our hypothesis that CXCR3 ligands exert a tumoursuppressive function in human ovarian cancer, we determined the association of their expression with patient survival. Tissue specimens from both cohorts were divided into a low (scores 0 and $1+)$ and a high expressing group (scores $2+$ and $3+$ ) for each chemokine. There was no statistically significant difference in PFS between CXCL9 and CXCL10 high or low expressing tumours. However, high expression was associated with a significantly better, approximately doubled, overall survival (OS) in the discovery set (Figure 2). For CXCL9 median, OS extended from $19 \pm 5.8$ to $48 \pm 3.5$ months (HR $0.41,95 \%$ CI $0.22-0.77, P=0.006$ ). For CXCL10 median, OS was $27 \pm 6.5$ and $49 \pm 3.8$ months (HR 0.46, 95\% CI $0.26-0.83 ; P=0.01)$ for the low- and high-expression groups, respectively. This could be validated in the validation set: for CXCL9 median OS was $24 \pm 3.9$ vs $48 \pm 5.9$ months (HR 0.60 , 95\% CI $0.39-0.92, P=0.02)$, for CXCL10 $31 \pm 5.4$ vs $46 \pm 6.1$ months (HR 0.52, 95\% CI 0.33-0.82, $P=0.005$ ) for the low and high expressing tumours, respectively. In the combined cohort, this survival advantage was more pronounced in patients without residual tumour (CXCL9: HR 0.39, 95\% CI 0.19-0.79; $P=0.009$; CXCL10: HR 0.35, 95\% CI 0.16-0.77; $P=0.009)$ than in patients with residual tumour (CXCL9: HR 0.63, 95\% CI 0.42-0.94, $P=0.02$; CXCL10: HR $0.70, \quad 95 \%$ CI $0.47-1.06 ; \quad P=0.09$; Supplementary Figure 1).

The combined overexpression of both chemokines had additional positive prognostic value. CXCL9 $9^{\text {high }} /$ CXCL10 $10^{\text {high }}$ tumours were indicative of a significantly better overall patient survival than tumours overexpressing only one of the two chemokines (HR 0.48, 95\% CI $0.26-0.88, P=0.019$; median OS $58 \pm 10.4$ vs $30 \pm 12.8$ months: Figure 2). Patients with CXCL9 ${ }^{\text {low }} /$ CXCL10 $10^{\text {low }}$ tumours had the worst prognosis with only 14-month median OS. There was no statistically significant difference in OS between the CXCL9 ${ }^{\text {low }} /$ CXCL10 $10^{\text {high }}$ and the CXCL $9^{\text {high }} /$ CXCL $10^{\text {low }}$ groups. The survival benefit of CXCL9 ${ }^{\text {high }} /$ CXCL10 $10^{\text {high }}$ tumours could be confirmed in the validation cohort (Figure 2).

Next, we performed a multivariate analysis using a COX proportional hazard model including postsurgical residual tumour mass, lymph node involvement, age and FIGO stage as covariates. In this model, CXCL9 and CXCL10 were identified as independent markers for a favourable patient prognosis in HGSC (Table 1).

TILs are positively correlated with CXCR3 ligands in HGSC. Next, we assessed whether the extent of infiltrating $\mathrm{CD}^{+} \mathrm{T}$ cells, $\mathrm{CD}^{+} 6^{+} \mathrm{NK}$ cells or $\mathrm{FOXP} 3^{+}$lymphocytes was correlated with the intratumoral concentration of CXCR3-binding chemokines. 

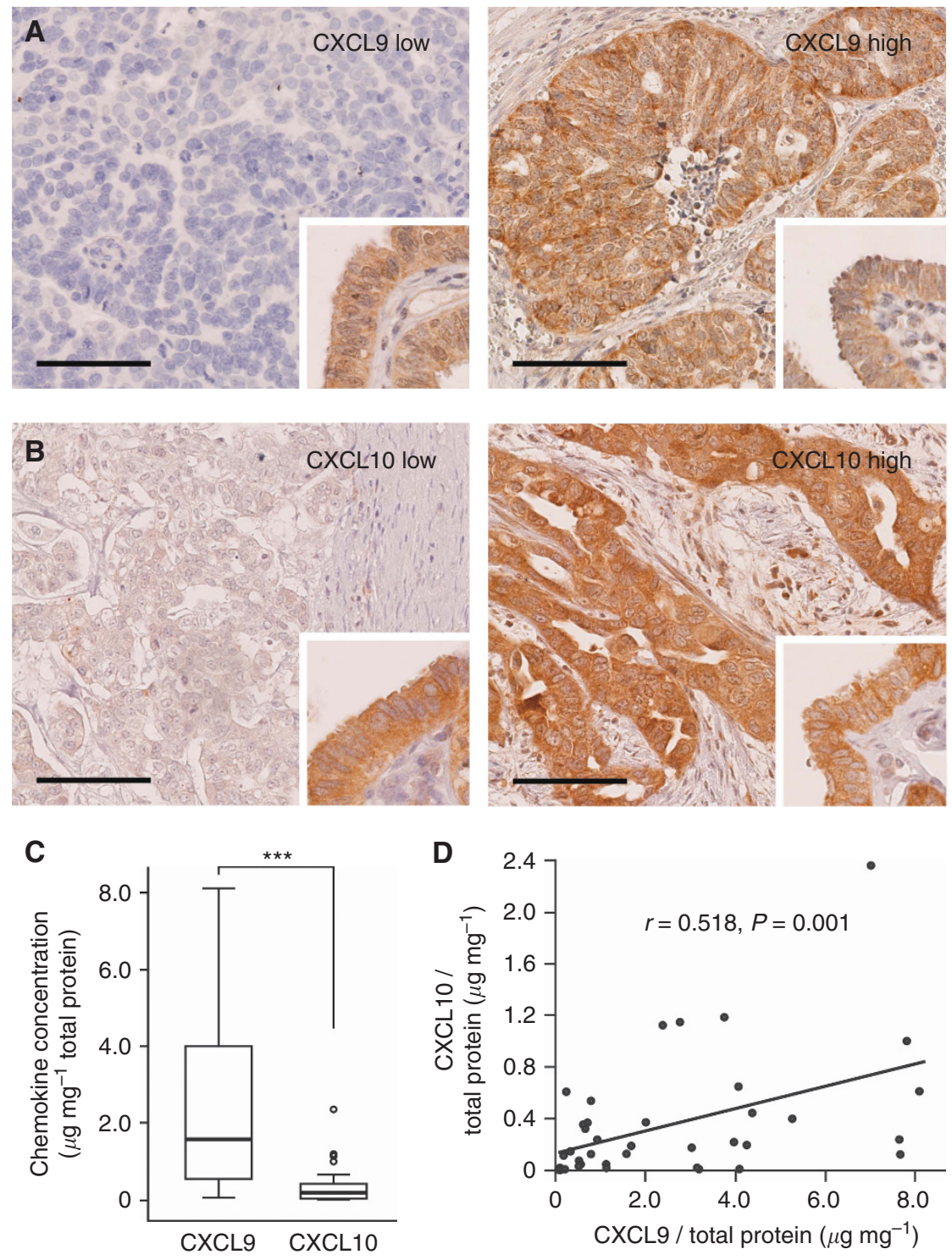

Figure 1. Expression of CXCL9 and CXCL10 in human high-grade serous ovarian cancers. (A and B) Immunhistochemical studies localise both chemokines predominantly to the tumour cell cytoplasm, with background staining in endothelial cells and some infiltrating immune cells. For subsequent analyses, chemokine expression was classified into a low (left panels)- and high (right panels)-expressing group. Fallopian tube epithelium served as a positive internal control (inserts). (C) Intratumoral CXCL9 and CXCL10 concentration was determined by ELISA in human serous ovarian cancer tissue extracts $(n=39)$ and is given in relation to the total protein concentration. ${ }^{\star \star \star} P \leq 0.001$. (D) Correlation between the relative concentrations of CXCL9 and CXCL10 in human ovarian cancer tissue extracts $(n=39)$. Scale bars in $\mathbf{A}$ and $\mathbf{B}, 100 \mu \mathrm{m}$.

Twenty-two HGSCs were available for parallel assessment of CXCL9 and CXCL10 concentration by ELISA and immunohistochemical staining of CD3 and CD56, 35 for the correlation with FOXP3. We observed a significant correlation between $\mathrm{CD}^{+} \mathrm{T}$ cells and CXCL10 expression levels $(r=0.547 ; P=0.019)$ as well as between $\mathrm{CD}^{+} 6^{+} \mathrm{NK}$ cells and CXCL10 $(r=0.588 ; P=0.017$; Figure $3 \mathrm{~A})$. A weak trend was observed for CXCL9 and the two lymphocytic subsets (Figure 3B;CD3: $r=0.418 ; P=0.085$; CD56: $r=0.314 ; P=0.236)$. CXCL9 was significantly associated with FOXP3 $^{+}$infiltration $(r=0.570 ; P<0.001)$, a weak trend was observed for CXCL10.

$\mathrm{CD}^{+}{ }^{+}, \mathrm{CD} 6^{+}$and FOXP3 ${ }^{+}$TILs, and patient prognosis. We further evaluated the prognostic impact of infiltrating lymphocytes, known to be recruited by CXCR3 ligands (Gorbachev et al, 2007; Wendel et al, 2008). Complete absence of infiltrating $\mathrm{CD}^{+}$or $\mathrm{CD}_{56}{ }^{+}$inflammatory cells (score 0 ) was not observed. Low (score $1-2+)$ and high infiltration (score $3+$ ) by $\mathrm{CD}^{+} \mathrm{T}$ cells were observed in $75.4 \%$ and $24.6 \%$, respectively. Low (score $1+$ ) and high infiltration (score $2-3+$ ) by $\mathrm{CD}^{2} 6^{+}$NK cells were observed in $44 \%$ and $56 \%$, respectively. Analysis of consecutive microscopic sections of the cancer tissues identified only a small population of $\mathrm{CD} 3{ }^{+} / \mathrm{CD} 6^{+}$double-positive NKT cells. A high amount of infiltrating $\mathrm{CD}^{+} \mathrm{T}$ cells was significantly associated with an improved PFS compared with low $\mathrm{CD}^{+}$infiltration (HR 0.42, 95\% CI $0.22-0.80 ; P=0.008$; median PFS $39 \pm 19.7$ vs $14 \pm 1.0$ months; Supplementary Figure 2A). A similar trend for better OS was observed, but was not statistically significant (HR 0.58, 95\% CI $0.30-1.14 ; P=0.12$; median OS $83 \pm 21.4$ vs $39 \pm 8.2$ months). We further investigated the prognostic impact of intraepithelial tumour-infiltrating $\mathrm{CD}^{+}{ }^{+} \mathrm{T}$ cells, defined as $\mathrm{T}$ cells in direct cell-to-cell contact with tumour cells, which were suggested as an even better prognostic marker than the total $\mathrm{CD}^{+}{ }^{+}$T-cell counts (Zhang et al, 2003). Intraepithelial tumour-infiltrating $\mathrm{CD}^{+}$ $\mathrm{T}$ cells were present in $68.7 \%$ of cases, but were not associated with PFS or OS in our cohort (Supplementary Figure 2B). 

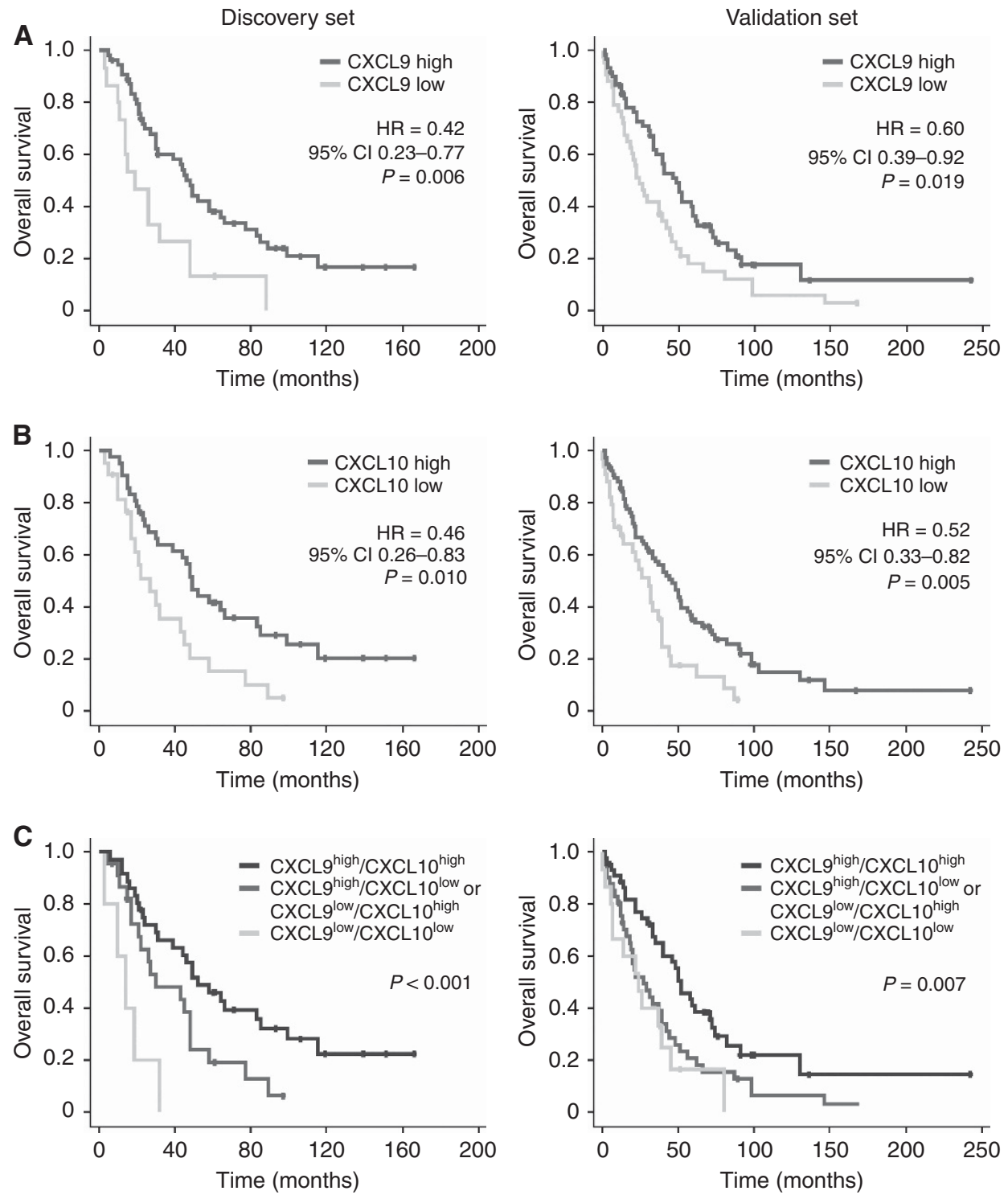

Figure 2. Prognostic significance of CXCL9 and CXCL10 expression in high-grade serous ovarian cancer. Kaplan-Meier curves for overall survival according to high or low CXCL9 (A) and CXCL10 (B) expression as determined by immunohistochemistry in the discovery set (left panels, $n=70$ ) and in the validation cohort (right panels, $n=114$ ). (C) Kaplan-Meier curves considering both CXCL9 and CXCL10 show a significantly better overall survival of patients whose tumours overexpress both chemokines compared with tumours overexpressing only one. There was no difference in survival between the CXCL9 $9^{\text {high }} / \mathrm{CXCL} 10^{\text {low }}$ and CXCL9low/CXCL10 $10^{\text {high }}$ groups.

\begin{tabular}{|c|c|c|c|}
\hline Variable & Hazard ratio & $95 \% \mathrm{Cl}$ & $P$ value \\
\hline CXCL9 expression (high vs low) & 0.62 & $0.42-0.94$ & 0.023 \\
\hline CXCL10 expression (high vs low) & 0.61 & $0.39-0.95$ & 0.029 \\
\hline Postsurgical residual tumour & 3.84 & $2.43-6.09$ & $<0.001$ \\
\hline Nodal status (positive vs negative) & 0.84 & $0.56-1.27$ & 0.409 \\
\hline Age & 1.01 & $0.99-1.03$ & 0.182 \\
\hline FIGO stage (IV vs III) & 2.00 & $1.28-3.13$ & 0.003 \\
\hline
\end{tabular}

Monitoring the extent of infiltrating $\mathrm{CD}_{5} 6^{+}$NK cells we observed an improved but not statistically significant OS associated with a high infiltration (median OS $58 \pm 25.2$ vs $30 \pm 5.0$ months, $P=0.17$; Supplementary Figure 2C). In addition, there was a higher 5-year OS in those patients whose tumours displayed a high lymphocytic infiltrate (CD3: 59\% vs 29\%; CD56: 50\% vs 29\%). FOXP3 was scored 0 in 10\% (5 out of 49), $1+$ in $49 \%$ (24 out of 49 ), $2+$ in $31 \%$ ( 15 out of 49 ) and $3+$ in $10 \%$ (5 out of 49$)$. The extent of the FOXP ${ }^{+}$lymphocytic infiltrate was not associated with PFS or OS in our cohort.

CXCL9 and CXCL10 are synergistically induced by inflammatory cytokines in human ovarian cancer cells. Our immunohistochemical analyses had revealed that CXCL9 and CXCL10 were mainly localised in the tumour cells. Thus, we used the two human ovarian cancer cell lines OV-MZ-6 and SKOV-3 as an in vitro model to explore the regulation of CXCR3-binding chemokines in ovarian cancer.

Ovarian cancer cells were exposed to different concentrations of interferon (IFN)- $\gamma$ and TNF- $\alpha$, two cytokines present in the ovarian cancer environment and well characterised as strong inducers of CXCR3 ligands (Takeyama et al, 1991; Rabinowich 

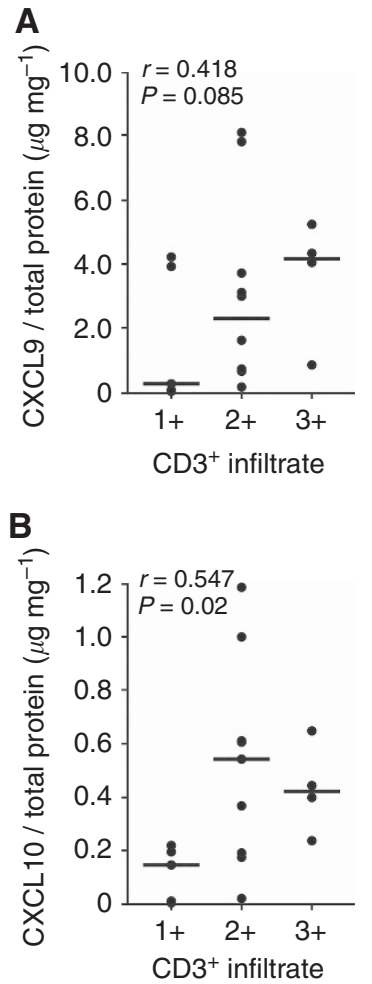
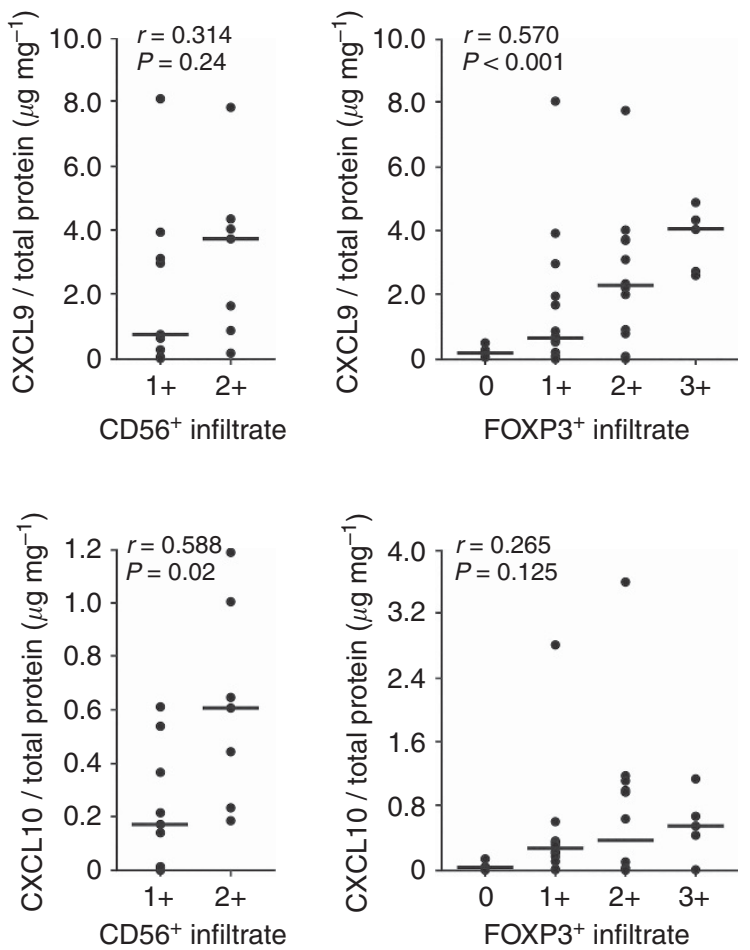

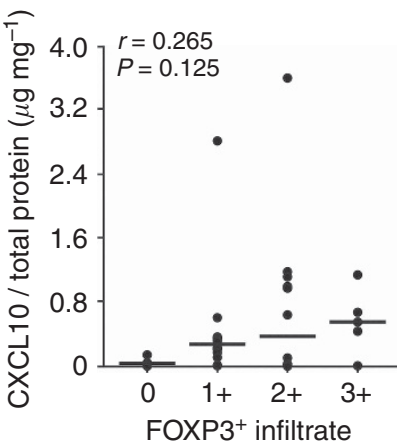

Figure 3. Association of CXCR3 ligand expression and tumour-infiltrating lymphocytes in serous ovarian cancers. Correlation of the immunohistochemically determined $\mathrm{CD}^{+}$(left panels), $\mathrm{CD}^{+} 6^{+}$(middle panels) and FOXP3 ${ }^{+}$immune infiltrates (right panels) with the intratumoral CXCL9 (A) and CXCL10 (B) concentration, respectively, as determined by ELISA in tissue extracts from serous ovarian cancers. Scale bars indicate median values.

et al, 1996). After $24 \mathrm{~h}$ of incubation, the content of secreted CXCL9 and CXCL10 was measured in the cell culture supernatants by ELISA (Figure 4A and B). Untreated SKOV-3 or OV-MZ-6 cells did not secrete either chemokine. Stimulation with IFN- $\gamma$ induced both chemokines in a dose-dependent manner. In contrast, TNF- $\alpha$ alone was only capable of inducing CXCL10, not CXCL9. Stimulation with both cytokines revealed a strong synergistic effect: $10 \mathrm{ng} \mathrm{ml}^{-1}$ IFN- $\gamma$ in combination with $10 \mathrm{ng} \mathrm{ml}^{-1} \mathrm{TNF}-\alpha$ increased the release of CXCL9 14-fold and 5-fold compared with $10 \mathrm{ng} \mathrm{ml}^{-1}$ IFN- $\gamma$ alone in OV-MZ-6 and SKOV-3 cells, respectively. Similarly, CXCL10 secretion was increased 100-fold and 4 -fold, respectively (Figure $4 \mathrm{~A}$ and $\mathrm{B}$ ).

IFN- $\gamma$ - and TNF- $\alpha$-induced chemokine release is mediated through the JAK/STAT and NF- $\boldsymbol{\kappa}$ B pathways. Next, we investigated the JAK/STAT and NF- $\kappa \mathrm{B}$ pathways both known to be involved in IFN $-\gamma$ and TNF- $\alpha$ receptor signalling (Clarke et $a l$, 2010). Ovarian cancer cells were exposed to the JAK/STAT inhibitor JAK inhibitor I or the NF- $\kappa$ B pathway inhibitors BAY 11-7082 (inhibiting $\mathrm{I} \kappa \mathrm{B}-\alpha$ kinase) or TPCK (preventing $\mathrm{I} \kappa \mathrm{B}-\alpha$ degradation) $30 \mathrm{~min}$ before adding IFN- $\gamma$ or TNF- $\alpha$. All three inhibitors blocked both IFN- $\gamma$ - and TNF- $\alpha$-mediated chemokine release in a dose-dependent manner (Figure $4 \mathrm{C}$ ). This was also true when cells were stimulated with IFN- $\gamma$ and TNF- $\alpha$ at the same time (data not shown). These results provide evidence for an involvement of the JAK/STAT and NF- $\kappa \mathrm{B}$ pathways in both IFN- $\gamma$ - and TNF- $\alpha$-induced CXCR3 ligand release in human ovarian cancer cells.

$\mathrm{PGE}_{2}$ inhibits IFN- $\gamma$-induced CXCL9 and CXCL10 release from human ovarian cancer cells. As overexpression of COX enzymes correlates with a reduced number of TILs in ovarian cancer (Liu et al, 2009), we evaluated the effect of major COX-metabolite $\mathrm{PGE}_{2}$ (Dannenberg and Subbaramaiah, 2003) on chemokine release from ovarian cancer cells. Thirty minutes before adding IFN- $\gamma$, ovarian cancer cells were exposed to different concentrations of $\mathrm{PGE}_{2}$. Although both cell lines display endogenous expression of both COX-1 and COX-2 (Figure 5A), additional $\mathrm{PGE}_{2}$ further suppressed IFN- $\gamma$-mediated secretion of CXCL9 and CXCL10 in a dose-dependent manner: $30 \mu \mathrm{M} \mathrm{PGE}_{2}$ approximately halved the secretion of each chemokine in both cell lines (Figure $5 \mathrm{~B}$ ).

COX inhibitor indomethacin increases IFN- $\gamma$-induced CXCL9 and CXCL10 release from human ovarian cancer cells. Next, we tested whether inhibition of both COX isoenzymes by indomethacin can increase chemokine release from ovarian cancer cells. Indomethacin $(30 \mu \mathrm{M}$ for $24 \mathrm{~h})$ enhanced the IFN- $\gamma$ mediated release of CXCL9 $\sim 2.2$-fold in OV-MZ-6 cells and 1.8-fold in SKOV-3 cells (Figure 5C). CXCL10 secretion was augmented 1.4-fold in OV-MZ-6 cells and 3.2-fold in SKOV-3 cells. Indomethacin alone without the inflammatory cytokines did not induce CXCL9 or CXCL10 in ovarian cancer cells (data not shown). MTT assays were conducted to rule out any bias of chemokine release due to changes in cell viability. No changes in cell viability were observed over $72 \mathrm{~h}$ of treatment with either $\mathrm{PGE}_{2}$ or indomethacin compared with unstimulated controls (data not shown).

High doses of the COX-2 selective inhibitor celecoxib decrease CXCL9 and CXCL10 release from human ovarian cancer cells through COX-independent effects. We next tested the effects of the COX-2 selective inhibitor celecoxib on CXCR3 ligand release, the only COX inhibitor prospectively evaluated therapeutically in human ovarian cancer (Reyners et al, 2012). In contrast to indomethacin, celecoxib did not significantly increase CXCL10 release from OV-MZ-6 cells (Figure 5D). In contrast, an inhibition of chemokine secretion was observed with $30 \mu \mathrm{m}$ celecoxib. In SKOV-3 cells, we noticed increased CXCL10 secretion at low celecoxib concentrations with a maximal increase by 2.4-fold at a concentration of $1 \mu \mathrm{M}$. Similar to OV-MZ-6, at higher 
A OV-MZ-6

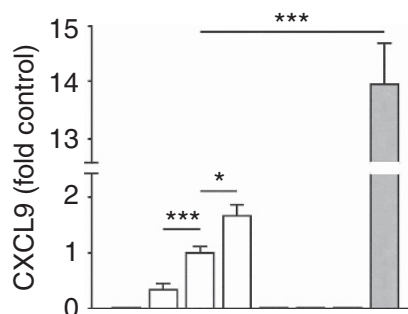

IFN- $\gamma\left(\mathrm{ng} \mathrm{ml}^{-1}\right)-2.51050--\quad 10$

TNF- $\alpha\left(\mathrm{ng} \mathrm{ml}^{-1}\right) \quad-\quad-2.5105010$

B

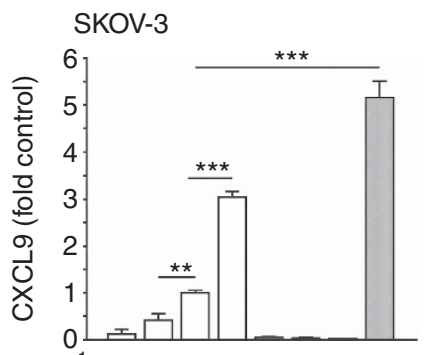

$\mathrm{IFN}-\gamma\left(\mathrm{ng} \mathrm{ml} \mathrm{l}^{-1}\right)-2.51050--\quad 10$

TNF- $\alpha\left(\mathrm{ng} \mathrm{ml}^{-1}\right)-\quad-\quad-2.5105010$

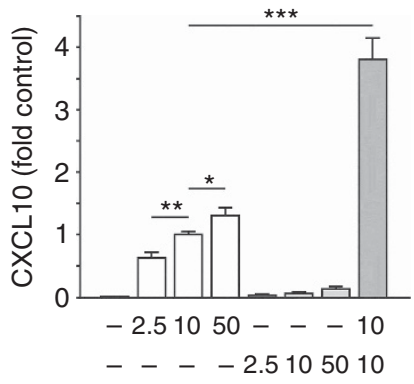

C
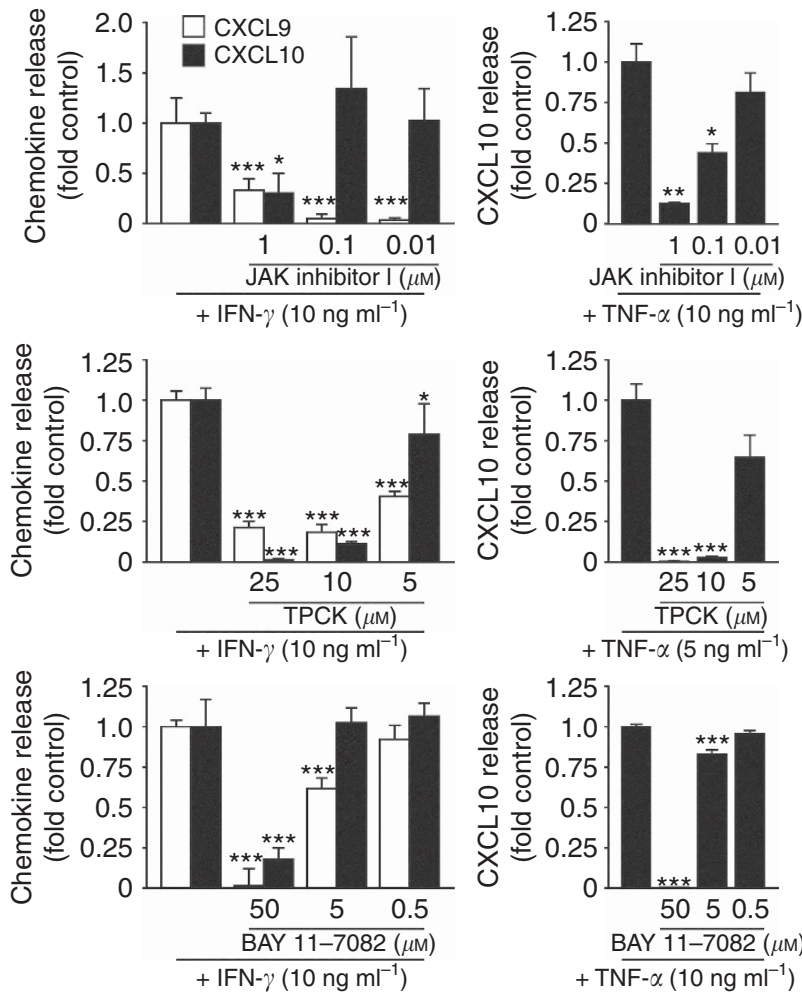

Figure 4. Synergistic induction of CXCL9 and CXCL10 by IFN- $\gamma$ and TNF- $\alpha$ in human ovarian cancer cell lines. OV-MZ-6 (A) and SKOV-3 (B) cells were stimulated with increasing concentrations of IFN- $\gamma$ and TNF- $\alpha$ as indicated. In both cell lines, both CXCL9 (left panels) and CXCL10 (right panels) were induced by IFN- $\gamma$ stimulation in a dose-dependent manner, whereas TNF- $\alpha$ had this effect only on CXCL10 secretion. (C-E) Cytokine-induced CXCL9 and CXCL10 secretion from ovarian cancer cells is dependent on the JAK/STAT and NF- $\kappa$ B signalling. Starved OV-MZ-6 cells were stimulated with IFN- $\gamma$ or TNF- $\alpha$ with increasing concentrations of JAK inhibitor I (C) or the NF- $\kappa$ B inhibitors TPCK (D) or BAY 11-7082 (E) for $24 \mathrm{~h}$. SKOV-3 cells revealed analogous results (data not shown). Asterisks mark significant differences compared with controls unless otherwise indicated.

concentrations, celecoxib significantly decreased CXCL10 release from SKOV-3 cells. Similar results were obtained for CXCL9 in both cell lines (data not shown). When the same experiments were conducted using TNF- $\alpha$ treatment instead of IFN- $\gamma$, we observed a significant decrease in CXCL10 release even at low celecoxib concentrations of $0.1 \mu \mathrm{M}$ (Figure 5D).

Subsequently, we assessed whether the observed inhibition of CXCR3 ligand secretion by celecoxib could be attributed to COX-independent effects. We therefore monitored NF- $\kappa \mathrm{B}$ activation in OV-MZ- 6 cells after stimulation with TNF- $\alpha$ in the absence or presence of different concentrations of celecoxib. TNF- $\alpha$ $\left(10 \mathrm{ng} \mathrm{ml}^{-1}\right)$ induced NF- $\kappa \mathrm{B}$ activation by $\sim 6$-fold when compared with unstimulated control cells. Celecoxib $(1 \mu \mathrm{M})$ did not influence this NF- $\kappa \mathrm{B}$ activation, whereas $30 \mu \mathrm{M}$ celecoxib resulted in a $50 \%$ decrease (Figure 5D). These differences were not attributable to the changes in cell viability, as demonstrated by MTT assays performed in parallel (data not shown).

COX-2 expression is inversely correlated with the intratumoral CXCL10 concentration. To find further support for a regulation of CXCR3 ligand secretion by cyclooxygenases in HGSC, we compared the relative chemokine concentrations measured by ELISA with COX expression detected by immunohistochemical staining in 23 patient samples (Figure 5E). COX-2 was inversely correlated with intratumoral CXCL10 concentration $(r=-0.46$; $P=0.05$, Figure 5E). However, no correlation was observed between COX-2 and CXCL9 expression or between COX-1 and chemokine expression. COX-1 and COX-2 expressions were not associated with patient survival (data not shown).

\section{DISCUSSION}

In the present study, we identified the CXCR3-binding chemokines CXCL9 and CXCL10 as independent favourable prognostic markers in advanced HGSC. The positive prognostic effect of high chemokine expression was independent of each other and of other clinicopathologic parameters. Our results further suggest that the recruitment of TILs by these chemokines may be an important mechanism of their tumour-suppressive function in ovarian cancer.

The number of $\mathrm{CD}^{+}$TILs was previously demonstrated to be a strong and independent prognostic marker in epithelial cancers including HGSC, possibly through recognition and eradication of cancer cells (Zhang et al, 2003; Tomsova et al, 2008; Chen and Mellman, 2013). In our study, a high frequency of CD3 ${ }^{+}$TILs was significantly associated with an improved PFS of 39 months compared with 14 months in patients with low $\mathrm{CD}^{+}{ }^{+}$infiltration and a higher 5-year OS, which is in line with these previous reports. In contrast, Sato et al (2005) found only the CD8 ${ }^{+}$ subpopulation of intratumoral $\mathrm{T}$ lymphocytes and especially the $\mathrm{CD}^{+}$/regulatory $\mathrm{T}$-cell ratio to be associated with improved survival, whereas no association was found for total $\mathrm{CD}^{+} \mathrm{T}$ cells or other subtypes of TILs. In agreement with other reports (Sato et al, 2005; Clarke et al, 2009; Mariya et al, 2014), we did not observe an association of intraepithelial $\mathrm{CD}^{+} \mathrm{T}$ cells with survival, which had been shown by the first mentioned studies (Zhang et al, 2003; Tomsova et al, 2008). Different cutoff values, a heterogeneous study population or different staining protocols 
A

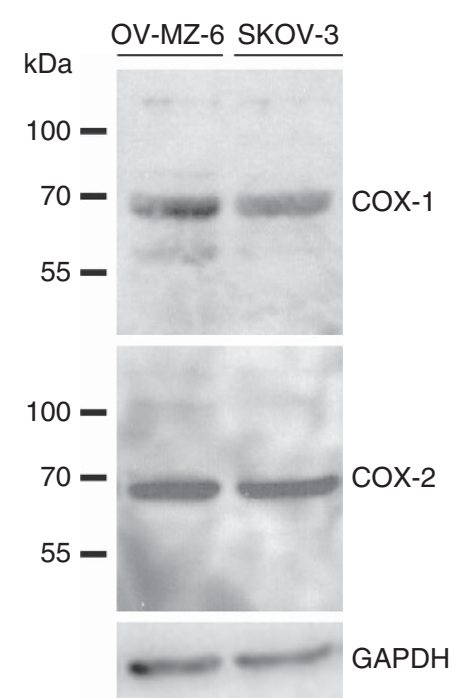

B

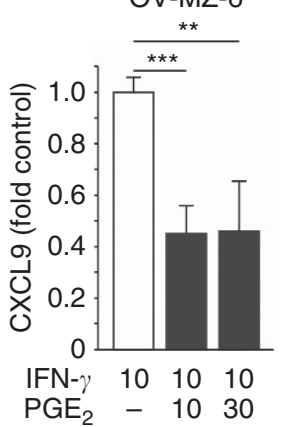

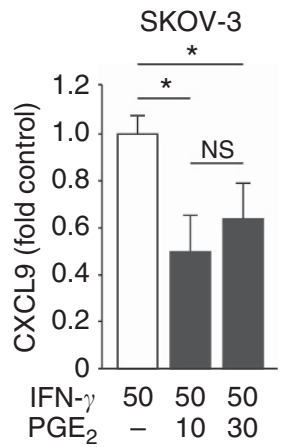

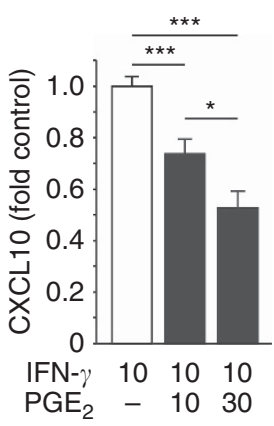

C

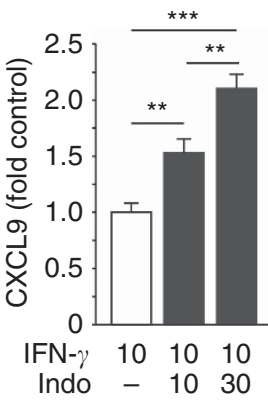

SKOV-3
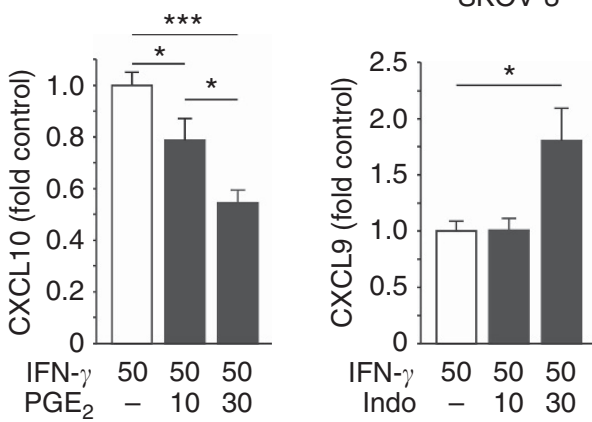

Indo - 1030
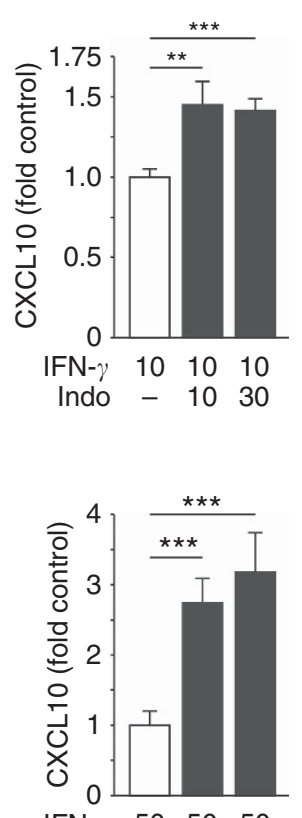

IFN- $\quad 50 \quad 50 \quad 50$ Indo - 1030
SKOV-3

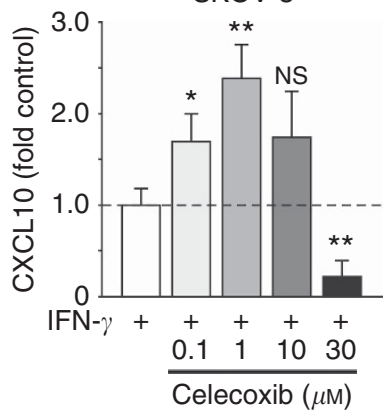

D

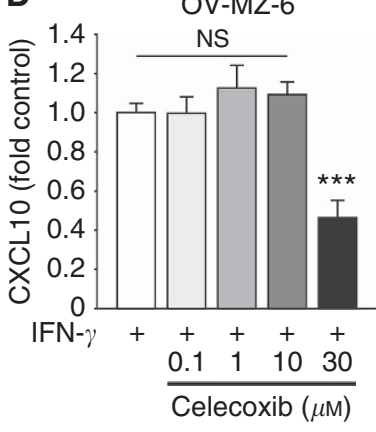

E

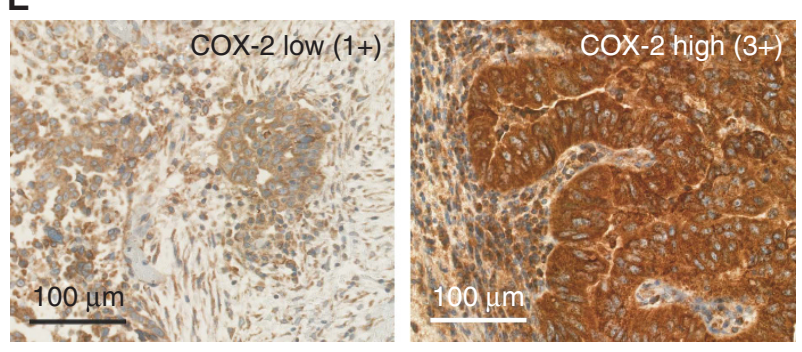

OV-MZ-6
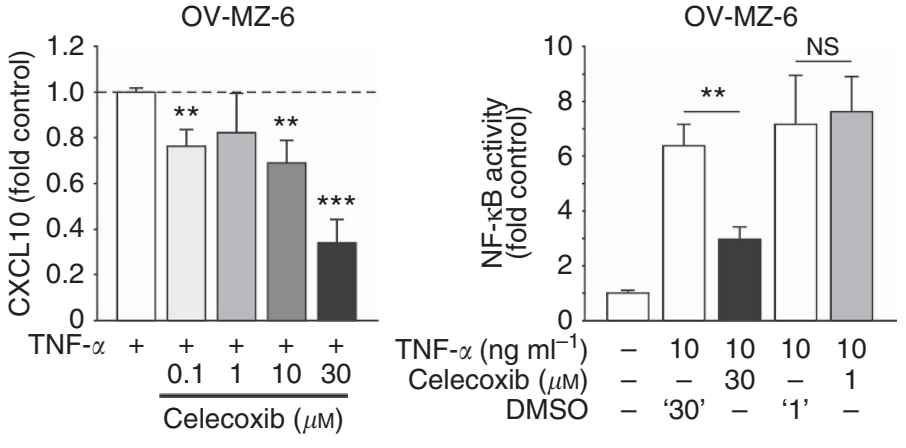
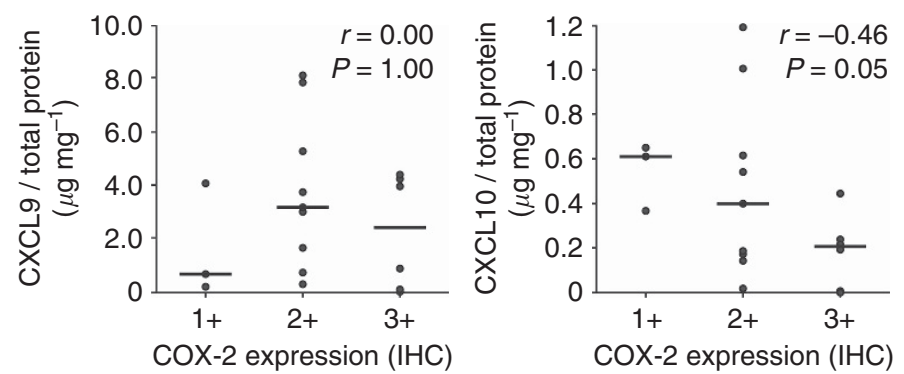

Figure 5. Modulation of CXCL9 and CXCL10 release from human ovarian cells by the COX system. (A) Western blots showing intrinsic COX-1 and COX-2 expression in OV-MZ-6 and SKOV-3 cells. (B) OV-MZ-6 and SKOV-3 cells were stimulated with increasing concentrations of PGE 2 (10 and $30 \mu \mathrm{M}$ ) for $30 \mathrm{~min}$ before adding IFN- $\gamma$. In both cell lines, PGE 2 suppressed IFN- $\gamma$-induced CXCL9 and CXCL10 release up to $~ 50 \%$. (C) The unselective COX inhibitor indomethacin was added $30 \mathrm{~min}$ before IFN- $\gamma$ on OV-MZ-6 or SKOV-3 cells and significantly enhanced the secretion of both chemokines. (D) Differential effect of the COX-2-specific inhibitor celecoxib on CXCL10 secretion from human ovarian cancer cells. In OV-MZ6 cells, there was no increase in CXCL10 secretion, in contrast to the effect seen for COX inhibition by indomethacin. In SKOV-3 cells, there was an increase in CXCL10 release only at low celecoxib concentrations ( 0.1 and $1 \mu \mathrm{M})$. In both cell lines, there was a significant inhibition of chemokine release at high $(30 \mu \mathrm{M})$ celecoxib concentrations. NF- $\kappa$ B activity measured by a reporter gene assay is increased approximately sevenfold $4 \mathrm{~h}$ after stimulation with $10 \mathrm{ng} \mathrm{ml}^{-1} \mathrm{TNF}-\alpha$ in OV-MZ-6 cells. Celecoxib $(1 \mu \mathrm{M})$ did not have any effect on NF- $\kappa$ B activity compared with vehicle control (' 1 '), whereas $30 \mu \mathrm{m}$ celecoxib significantly reduces TNF- $\alpha$-induced NF- $\kappa$ B activity. (E) Correlation of COX-2 expression and CXCL9 and CXCL10 expression in human ovarian cancer. COX-2 expression was assessed semi-quantitatively by immunohistochemistry in primary high-grade serous ovarian cancer samples. Correlation of COX-2 expression with the intratumoral chemokine concentration measured by ELISA ( $n=18$ ) reveals no correlation between COX-2 and CXCL9, but a significant inverse correlation with CXCL10. Scale bars in E indicate median values. Asterisks mark significant differences compared with controls unless indicated otherwise. 
might account for these discrepancies. Moreover, tumour-promoting subpopulations of $\mathrm{CD}^{+}{ }^{+} \mathrm{T}$ lymphocytes such as FOXP3 ${ }^{+}$ regulatory $\mathrm{T}$ cells might account for the less strong effect of $\mathrm{CD} 3$ as compared with CD8.

CXCL9 and CXCL10 have previously been demonstrated to be involved in the chemotactic recruitment of tumour-suppressive TILs in mouse models of epithelial cancers (Yang et al, 2006; Gorbachev et al, 2007; Wendel et al, 2008). Zhang et al (2003) demonstrated that ovarian cancers containing intratumoral CD3 ${ }^{+}$ T lymphocytes exhibit higher levels of CXCL9 (Mig) messenger RNA (mRNA) than tumours lacking T cells. Similarly, CXCL9 and CXCL10 mRNA has been shown to be associated with the CD8 ${ }^{+}$ T-cell infiltration (Kryczek et al, 2009). Our study extends these results by demonstrating a direct correlation between CXCL10 protein and higher $\mathrm{CD}^{+}$lymphocytic infiltrate in serous ovarian cancers. Although CXCL9 protein expression was also significantly associated with better prognosis, overexpression did not correlate with TILs. This antitumour activity may partly be explained by mechanisms other than lymphocyte recruitment such as T-cell activation, which was recently demonstrated in a mouse model of breast cancer (Markosyan et al, 2013). There was only a moderate correlation between intratumoral CXCL9 and CXCL10, which might be explained by different regulatory mechanisms within the tumour microenvironment, illustrated, for example, by the different sensitivity to TNF- $\alpha$-mediated induction in ovarian cancer cells in our experiments (Figure 4).

A novelty of our results is the demonstration of a strong and independent prognostic value for both CXCL9 and CXCL10, suggesting a tumour-suppressive net effect in serous ovarian cancer. There is evidence that both chemokines can also exert tumour-promoting effects in addition to their tumour-suppressive function, such as through chemotactic recruitment of tumourpromoting regulatory $\mathrm{T}$ cells (Redjimi et al, 2012) or chemotaxis inhibition by truncated CXCL10 (Rainczuk et al, 2014). Regulatory $\mathrm{T}$ cells may secrete VEGF, which in turn impairs the angiostatic activity of CXCR3 chemokines and may indirectly enhance lymphocyte maturation towards regulatory $\mathrm{T}$ cells (Gasparri et al, 2013). Hence, there might be a synergistic effect of CXCL9/ 10 upregulating agents and anti-VEGF treatment. Indeed, we also observed a positive correlation between $\mathrm{FOXP}^{+}{ }^{+}$regulatory T-cell infiltration and intratumoral CXCR3 ligand concentration, which supports the data by Redjimi et al (2012). However, our survival analyses suggest that the recruitment of tumour-suppressive T-cell subsets and possibly additional antitumor effects such as T-cell activation outbalance possible tumour-promoting effects of CXCR3 ligands in ovarian cancer.

It remains speculative at this time if CXCR3 ligands are a priori present in the tumour microenvironment, for example, through the secretion by macrophages or tumour cells and subsequently attract $\mathrm{T}$ lymphocytes, or if $\mathrm{T}$ cells initially recruited into the tumour by stimuli other than CXCR3 ligands secrete IFN- $\gamma$ that in turn causes chemokine production by tumour cells. Nevertheless, augmenting CXCR3 ligand secretion from cancer cells may enhance antitumour immunity through recruitment of tumour-suppressive TILs. We therefore investigated potential pharmacologic mechanisms to modulate chemokine secretion from ovarian cancer cells.

COX overexpression in clinical samples of ovarian cancer was previously shown to be significantly associated with a lower number of TILs and worse patient prognosis (Denkert et al, 2002; Liu et al, 2009). We therefore investigated the COX system as a potential target to enhance TIL recruitment. Unselective COX inhibition by indomethacin significantly increased CXCL9 and CXCL10 secretion from human ovarian cancer cells. In support of these in vitro findings, we demonstrated that CXCL10 and COX-2 expression levels are inversely correlated in clinical samples of HGSC. Our suggestion of therapeutic COX modulation is further supported by functional studies, in which indomethacin hampered tumour growth and metastatic spread in an NK cell or T-celldependent manner in murine cancer models (Kundu and Fulton, 2002; Kundu et al, 2005). Similarly, COX inhibition enhanced the $\mathrm{CD} 4{ }^{+}$Th1 lymphocytic infiltrate and improved the efficacy of cancer vaccines in preclinical lung cancer models (Sharma et al, 2005; Haas et al, 2006). In murine colon cancer cells, the addition of indomethacin to an IFN-based treatment improved ex vivo $\mathrm{CD}^{+}$T-cell recruitment (Muthuswamy et al, 2012). Our results provide a scientific basis for the future implementation of COX inhibitors as an adjunct to chemo- and/or immunotherapies in therapeutic trials of high-grade serous cancer. The therapeutic modulation of chemokine secretion and TILs through COX inhibition is particularly interesting, as a number of different inhibitors with well-defined pharmacologic profiles is available for clinical use.

Targeting COX in ovarian cancer is not a new approach. However, to our knowledge the only COX inhibitor tested so far in a prospective, randomised clinical trial of ovarian cancer is the COX-2-specific inhibitor celecoxib. Its addition to a standard firstline chemotherapy of carboplatin plus docetaxel did not improve patient survival and had severe side effects, particularly skin reactions, leading to premature stopping of celecoxib in $24 \%$ of patients (Reyners et al, 2012). The current study provides a potential explanation for this contradictory finding in ovarian cancer: whereas COX inhibition by indomethacin increased chemokine secretion from ovarian cancer cells, celecoxib reduced CXCL9 and CXCL10 release in a dose-dependent manner through the COX-independent effects, most likely through the inhibition of $\mathrm{NF}-\kappa \mathrm{B}$. This is in line with prior reports favouring unspecific or COX-1 inhibition in ovarian cancer (Gupta et al, 2003; Daikoku et al, 2005).

In conclusion, we demonstrated for the first time that the two CXCR3-binding chemokines CXCL9 and CXCL10 are independent predictors of an improved OS in HGSC. Furthermore, we identified the COX system as a suitable pharmacologic target to augment intratumoral chemokine concentrations. On the basis of our results, the addition of indomethacin, rather than celecoxib, to immunotherapies in future clinical trials should be explored, with the goal to improve their efficacy by enhancing the tumour-suppressive lymphocytic infiltration in ovarian cancer.

\section{ACKNOWLEDGEMENTS}

We thank Alexandra Stöckel, Sandra Baur, Anke Benge and Rosalinde Bräuer for excellent technical assistance. We thank Dr Alexander Hapfelmeier for providing statistical analyses of the data. Dr Stefanie Avril is supported by the Clinical and Translational Science Collaborative of Cleveland, KL2TR000440 from the National Center for Advancing Translational Sciences component of the National Institutes of Health and NIH roadmap for Medical Research. This work was supported by a grant from the Deutsche Forschungsgemeinschaft to HB (BR 4733/1-1).

\section{CONFLICT OF INTEREST}

The authors declare no conflict of interest.

\section{REFERENCES}

Abastado JP (2012) The next challenge in cancer immunotherapy: controlling T-cell traffic to the tumor. Cancer Res 72: 2159-2161.

Bellati F, Napoletano C, Gasparri ML, Ruscito I, Marchetti C, Pignata S, Tomao F, Benedetti Panici P, Nuti M (2012) Current knowledge and open 
issues regarding bevacizumab in gynaecological neoplasms. Crit Rev Oncol Hematol 83: 35-46.

Bellati F, Napoletano C, Ruscito I, Visconti V, Antonilli M, Gasparri ML, Zizzari IG, Rahimi H, Palaia I, Rughetti A, Benedetti Panici P, Nuti M (2013) Past, present and future strategies of immunotherapy in gynecological malignancies. Curr Mol Med 13: 648-669.

Bronger H, Konig J, Kopplow K, Steiner HH, Ahmadi R, Herold-Mende C, Keppler D, Nies AT (2005) ABCC drug efflux pumps and organic anion uptake transporters in human gliomas and the blood-tumor barrier. Cancer Res 65: 11419-11428.

Bronger H, Kraeft S, Schwarz-Boeger U, Cerny C, Stöckel A, Avril S, Kiechle M, Schmitt M (2012) Modulation of CXCR3 ligand secretion by prostaglandin E2 and cyclooxygenase inhibitors in human breast cancer. Breast Cancer Res 14: R30.

Chen DS, Mellman I (2013) Oncology meets immunology: the cancerimmunity cycle. Immunity 39: 1-10.

Clarke B, Tinker AV, Lee CH, Subramanian S, van de Rijn M, Turbin D, Kalloger S, Han G, Ceballos K, Cadungog MG, Huntsman DG, Coukos G, Gilks CB (2009) Intraepithelial T cells and prognosis in ovarian carcinoma: novel associations with stage, tumor type, and BRCA1 loss. Mod Pathol 22: 393-402.

Clarke DL, Clifford RL, Jindarat S, Proud D, Pang L, Belvisi M, Knox AJ (2010) TNFalpha and IFNgamma synergistically enhance transcriptional activation of CXCL10 in human airway smooth muscle cells via STAT-1, NF-kappaB, and the transcriptional coactivator CREB-binding protein. J Biol Chem 285: 29101-29110.

Daikoku T, Wang D, Tranguch S, Morrow JD, Orsulic S, DuBois RN, Dey SK (2005) Cyclooxygenase- 1 is a potential target for prevention and treatment of ovarian epithelial cancer. Cancer Res 65: 3735-3744.

Dannenberg AJ, Subbaramaiah K (2003) Targeting cyclooxygenase-2 in human neoplasia: rationale and promise. Cancer Cell 4: 431-436.

Denkert C, Kobel M, Pest S, Koch I, Berger S, Schwabe M, Siegert A, Reles A, Klosterhalfen B, Hauptmann S (2002) Expression of cyclooxygenase 2 is an independent prognostic factor in human ovarian carcinoma. Am J Pathol 160: 893-903.

Denkert C, Loibl S, Noske A, Roller M, Muller BM, Komor M, Budczies J, Darb-Esfahani S, Kronenwett R, Hanusch C, von Torne C, Weichert W, Engels K, Solbach C, Schrader I, Dietel M, von Minckwitz G (2010) Tumor-associated lymphocytes as an independent predictor of response to neoadjuvant chemotherapy in breast cancer. J Clin Oncol 28: $105-113$.

Furuya M, Suyama T, Usui H, Kasuya Y, Nishiyama M, Tanaka N, Ishiwata I, Nagai Y, Shozu M, Kimura S (2007) Up-regulation of CXC chemokines and their receptors: implications for proinflammatory microenvironments of ovarian carcinomas and endometriosis. Hum Pathol 38: 1676-1687.

Gasparri ML, Attar R, Palaia I, Perniola G, Marchetti C, Di Donato V, Farooqi AA, Papadia A, Panici PB (2015) Tumor infiltrating lymphocytes in ovarian cancer. Asian Pac J Cancer Prev 16: 3635-3638.

Gasparri ML, Bellati F, Napoletano C, Panici PB, Nuti M (2013) Interaction between Treg cells and angiogenesis: a dark double track. Int $J$ Cancer 132: 2469.

Gorbachev AV, Kobayashi H, Kudo D, Tannenbaum CS, Finke JH, Shu S, Farber JM, Fairchild RL (2007) CXC chemokine ligand 9/monokine induced by IFN-gamma production by tumor cells is critical for T cellmediated suppression of cutaneous tumors. J Immunol 178: 2278-2286.

Gupta RA, Tejada LV, Tong BJ, Das SK, Morrow JD, Dey SK, DuBois RN (2003) Cyclooxygenase-1 is overexpressed and promotes angiogenic growth factor production in ovarian cancer. Cancer Res 63: 906-911.

Haas AR, Sun J, Vachani A, Wallace AF, Silverberg M, Kapoor V, Albelda SM (2006) Cycloxygenase-2 inhibition augments the efficacy of a cancer vaccine. Clin Cancer Res 12: 214-222.

Hsin LJ, Kao HK, Chen IH, Tsang NM, Hsu CL, Liu SC, Chang YS, Chang KP (2013) Serum CXCL9 levels are associated with tumor progression and treatment outcome in patients with nasopharyngeal carcinoma. PLoS One 8: e80052.

Kandalaft LE, Powell Jr. DJ, Singh N, Coukos G (2011) Immunotherapy for ovarian cancer: what's next? J Clin Oncol 29: 925-933.

Kohrt HE, Houot R, Marabelle A, Cho HJ, Osman K, Goldstein M, Levy R, Brody J (2012) Combination strategies to enhance antitumor ADCC. Immunotherapy 4: 511-527.

Kondo T, Ito F, Nakazawa H, Horita S, Osaka Y, Toma H (2004) High expression of chemokine gene as a favorable prognostic factor in renal cell carcinoma. J Urol 171: 2171-2175.
Kryczek I, Banerjee M, Cheng P, Vatan L, Szeliga W, Wei S, Huang E, Finlayson E, Simeone D, Welling TH, Chang A, Coukos G, Liu R, Zou W (2009) Phenotype, distribution, generation, and functional and clinical relevance of Th17 cells in the human tumor environments. Blood 114: 1141-1149.

Kundu N, Fulton AM (2002) Selective cyclooxygenase (COX)-1 or COX-2 inhibitors control metastatic disease in a murine model of breast cancer. Cancer Res 62: 2343-2346.

Kundu N, Walser TC, Ma X, Fulton AM (2005) Cyclooxygenase inhibitors modulate NK activities that control metastatic disease. Cancer Immunol Immunother 54: 981-987.

Leone Roberti Maggiore U, Bellati F, Ruscito I, Gasparri ML, Alessandri F, Venturini PL, Ferrero S (2013) Monoclonal antibodies therapies for ovarian cancer. Expert Opin Biol Ther 13: 739-764.

Liu M, Matsumura N, Mandai M, Li K, Yagi H, Baba T, Suzuki A, Hamanishi J, Fukuhara K, Konishi I (2009) Classification using hierarchical clustering of tumor-infiltrating immune cells identifies poor prognostic ovarian cancers with high levels of COX expression. Mod Pathol 22: 373-384.

Lunardi S, Jamieson NB, Lim SY, Griffiths KL, Carvalho-Gaspar M, Al-Assar O, Yameen S, Carter RC, McKay CJ, Spoletini G, D’Ugo S, Silva MA, Sansom OJ, Janssen KP, Muschel RJ, Brunner TB (2014) IP-10/CXCL10 induction in human pancreatic cancer stroma influences lymphocytes recruitment and correlates with poor survival. Oncotarget 5 : 11064-11080.

Mariya T, Hirohashi Y, Torigoe T, Asano T, Kuroda T, Yasuda K, Mizuuchi M, Sonoda T, Saito T, Sato N (2014) Prognostic impact of human leukocyte antigen class I expression and association of platinum resistance with immunologic profiles in epithelial ovarian cancer. Cancer Immunol Res 2: 1220-1229.

Markosyan N, Chen EP, Evans RA, Ndong V, Vonderheide RH, Smyth EM (2013) Mammary carcinoma cell derived cyclooxygenase 2 suppresses tumor immune surveillance by enhancing intratumoral immune checkpoint activity. Breast Cancer Res 15: R75.

Möbus V, Gerharz CD, Press U, Moll R, Beck T, Mellin W, Pollow K, Knapstein PG, Kreienberg R (1992) Morphological, immunohistochemical and biochemical characterization of 6 newly established human ovarian carcinoma cell lines. Int J Cancer 52: 76-84.

Müller MA, Opfer J, Brunie L, Volkhardt LA, Sinner EK, Boettiger D, Bochen A, Kessler H, Gottschalk KE, Reuning U (2013) The glycophorin A transmembrane sequence within integrin alphavbeta 3 creates a nonsignaling integrin with low basal affinity that is strongly adhesive under force. J Mol Biol425 2988-3006.

Muthuswamy R, Berk E, Junecko BF, Zeh HJ, Zureikat AH, Normolle D, Luong TM, Reinhart TA, Bartlett DL, Kalinski P (2012) NF-kappaB hyperactivation in tumor tissues allows tumor-selective reprogramming of the chemokine microenvironment to enhance the recruitment of cytolytic T effector cells. Cancer Res 72: 3735-3743.

Rabinowich H, Suminami Y, Reichert TE, Crowley-Nowick P, Bell M, Edwards R, Whiteside TL (1996) Expression of cytokine genes or proteins and signaling molecules in lymphocytes associated with human ovarian carcinoma. Int J Cancer 68: 276-284.

Rainczuk A, Rao JR, Gathercole JL, Fairweather NJ, Chu S, Masadah R, Jobling TW, Deb-Choudhury S, Dyer J, Stephens AN (2014) Evidence for the antagonistic form of CXC-motif chemokine CXCL10 in serous epithelial ovarian tumours. Int J Cancer 134: 530-541.

Redjimi N, Raffin C, Raimbaud I, Pignon P, Matsuzaki J, Odunsi K, Valmori D, Ayyoub M (2012) CXCR3 + T regulatory cells selectively accumulate in human ovarian carcinomas to limit type I immunity. Cancer Res 72: 4351-4360.

Reyners AK, de Munck L, Erdkamp FL, Smit WM, Hoekman K, Lalisang RI, de Graaf H, Wymenga AN, Polee M, Hollema H, van Vugt MA, Schaapveld M, Willemse PH (2012) A randomized phase II study investigating the addition of the specific COX-2 inhibitor celecoxib to docetaxel plus carboplatin as first-line chemotherapy for stage IC to IV epithelial ovarian cancer, Fallopian tube or primary peritoneal carcinomas: the DoCaCel study. Ann Oncol 23: 2896-2902.

Sato E, Olson SH, Ahn J, Bundy B, Nishikawa H, Qian F, Jungbluth AA, Frosina D, Gnjatic S, Ambrosone C, Kepner J, Odunsi T, Ritter G, Lele S, Chen YT, Ohtani H, Old LJ, Odunsi K (2005) Intraepithelial CD8 + tumor-infiltrating lymphocytes and a high $\mathrm{CD} 8+$ /regulatory $\mathrm{T}$ cell ratio are associated with favorable prognosis in ovarian cancer. Proc Natl Acad Sci USA 102: 18538-18543. 
Schmalfeldt B, Kuhn W, Reuning U, Pache L, Dettmar P, Schmitt M, Janicke F, Hofler H, Graeff H (1995) Primary tumor and metastasis in ovarian cancer differ in their content of urokinase-type plasminogen activator, its receptor, and inhibitors types 1 and 2. Cancer Res 55: 3958-3963.

Sharma S, Zhu L, Yang SC, Zhang L, Lin J, Hillinger S, Gardner B, Reckamp K, Strieter RM, Huang M, Batra RK, Dubinett SM (2005) Cyclooxygenase 2 inhibition promotes IFN-gamma-dependent enhancement of antitumor responses. J Immunol 175: 813-819.

Shuptrine CW, Surana R, Weiner LM (2012) Monoclonal antibodies for the treatment of cancer. Semin Cancer Biol 22: 3-13.

Specht K, Harbeck N, Smida J, Annecke K, Reich U, Nährig J, Langer R, Mages J, Busch R, Kruse E, Klein-Hitpass L, Schmitt M, Kiechle M, Höfler H (2009) Expression profiling identifies genes that predict recurrence of breast cancer after adjuvant CMF-based chemotherapy. Breast Cancer Res Treat 118: 45-56.

Suyama T, Furuya M, Nishiyama M, Kasuya Y, Kimura S, Ichikawa T, Ueda T, Nikaido T, Ito H, Ishikura H (2005) Up-regulation of the interferon gamma (IFN-gamma)-inducible chemokines IFN-inducible T-cell alpha chemoattractant and monokine induced by IFN-gamma and of their receptor CXC receptor 3 in human renal cell carcinoma. Cancer 103: 258-267.

Takeyama H, Wakamiya N, O'Hara C, Arthur K, Niloff J, Kufe D, Sakarai K, Spriggs D (1991) Tumor necrosis factor expression by human ovarian carcinoma in vivo. Cancer Res 51: 4476-4480.

The Cancer Genome Atlas Research Network (2011) Integrated genomic analyses of ovarian carcinoma. Nature 474: 609-615.

Tomsova M, Melichar B, Sedlakova I, Steiner I (2008) Prognostic significance of $\mathrm{CD} 3$ + tumor-infiltrating lymphocytes in ovarian carcinoma. Gynecol Oncol 108: 415-420.
Tothill RW, Tinker AV, George J, Brown R, Fox SB, Lade S, Johnson DS, Trivett MK, Etemadmoghadam D, Locandro B, Traficante N, Fereday S, Hung JA, Chiew YE, Haviv I, Gertig D, DeFazio A, Bowtell DD (2008) Novel molecular subtypes of serous and endometrioid ovarian cancer linked to clinical outcome. Clin Cancer Res 14: 5198-5208.

Tymoszuk P, Charoentong P, Hackl H, Spilka R, Muller-Holzner E, Trajanoski Z, Obrist P, Revillion F, Peyrat JP, Fiegl H, Doppler W (2014) High STAT1 mRNA levels but not its tyrosine phosphorylation are associated with macrophage infiltration and bad prognosis in breast cancer. BMC Cancer 14: 257.

Wendel M, Galani IE, Suri-Payer E, Cerwenka A (2008) Natural killer cell accumulation in tumors is dependent on IFN-gamma and CXCR3 ligands. Cancer Res 68: 8437-8445.

Yang X, Chu Y, Wang Y, Zhang R, Xiong S (2006) Targeted in vivo expression of IFN-gamma-inducible protein 10 induces specific antitumor activity. J Leukoc Biol 80: 1434-1444.

Zhang L, Conejo-Garcia JR, Katsaros D, Gimotty PA, Massobrio M, Regnani G, Makrigiannakis A, Gray H, Schlienger K, Liebman MN, Rubin SC, Coukos G (2003) Intratumoral T cells, recurrence, and survival in epithelial ovarian cancer. $N$ Engl J Med 348: 203-213.

This work is published under the standard license to publish agreement. After 12 months the work will become freely available and the license terms will switch to a Creative Commons AttributionNonCommercial-Share Alike 4.0 Unported License.

Supplementary Information accompanies this paper on British Journal of Cancer website (http://www.nature.com/bjc) 